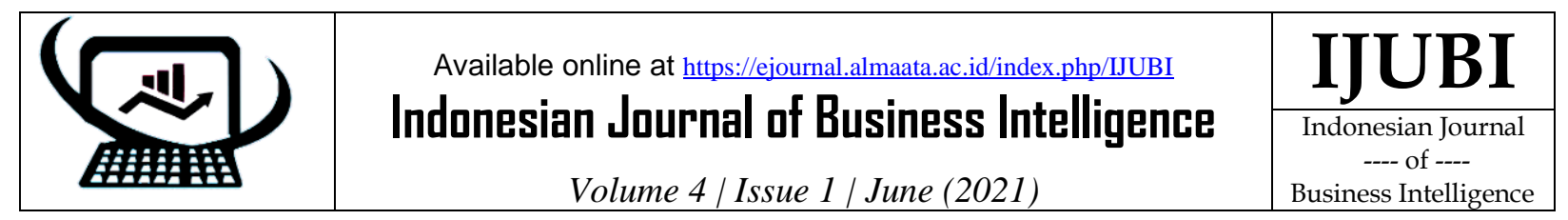

\title{
ANALISIS ANTENATAL CARE (ANC) PADA SURVEILANS KESEHATAN IBU DAN ANAK DENGAN TAHAPAN AGREGASI PIPELINE NOSQL
}

Dadang Heksaputra ${ }^{1}$, M. J. U. Haris Bahrudin ${ }^{2}$, Anni Karimatul Fauziyah' ${ }^{3}$, Dhina Puspasari Wijaya ${ }^{4}$

1,2Information System, Faculty of Computer, Universitas Alma Ata,

3,4Informatics, Faculty of Computer, Universitas Alma Ata

dadang@almaata.ac.id

Jl. Brawijaya 99, Yogyakarta, Indonesia 55183

Keywords:

child, mother, health, monitoring, NoSQL.

\section{Kata Kunci:}

anak, ibu, kesehatan, pemantauan, NoSQL.

\begin{abstract}
Case 30.8 percent of Indonesian children under five are stunted. Bantul is a district in the Province of D.I. Yogyakarta, Indonesia, is a locus of stunting. Bantul has ten villages. The ten villages include Patalan Jetis Village, Canden Jetis Village, Terong Dlingo Village, Argodadi Sedayu Village, Triharjo Pandak Village, Triwidadi Pajangan Village, Jatimulyo Dlingo Village, Datangharjo Sewon Village, Sendangsari Pajangan Village, and Trimulyo Jetis Village. The research focuses on the village of Argodadi Sedayu. In the village of Argodadi Sedayu, Antenatal Care (ANC) research would be conducted. Antenatal Care (ANC) is a pregnancy check by a doctor or midwife. Therefore, Antenatal Care Analysis (ANC) is needed to determine whether diet, parenting, and sanitation are well programmed. Antenatal care (ANC) research framework was a model of method improvement. The method improvement model consists of indicators, proposed methods, objectives, and measurements. The indicators consist of monitoring instruments and health visits. The proposed method uses an aggregation pipeline stage. The data was processed in the aggregation pipeline stage. The data were obtained from the time series data surveillance dataset. The research objective was to analyze the research results accurately according to the proposed method. Measurement of indicator analysis with the application of the dashboard as a performance indicator on the research results. Practically, it is hoped that the research results could consider the health office and related institutions in reducing or even elevating Argodadi Sedayu Village in Yogyakarta as a non-locus of stunting using massive monitoring of diet, parenting, and sanitation well programmed.
\end{abstract}

\section{Abstrak}

Kasus 30,8 persen anak Indonesia di bawah lima tahun mengalami stunting. Bantul merupakan sebuah kabupaten di Provinsi D.I. Yogyakarta, Indonesia, adalah tempat terjadinya stunting. Bantul memiliki sepuluh desa. Sepuluh desa tersebut antara lain Desa Patalan Jetis, Desa Canden Jetis, Desa Terong Dlingo, Desa Argodadi Sedayu, Desa Triharjo Pandak, Desa Triwidadi Pajangan, Desa Jatimulyo Dlingo, Desa Datangharjo Sewon, Desa Sendangsari Pajangan, dan Desa Trimulyo Jetis. Penelitian difokuskan di Desa Argodadi Sedayu. Di Desa Argodadi Sedayu akan dilakukan penelitian Antenatal Care (ANC). Antenatal Care (ANC) adalah pemeriksaan kehamilan oleh dokter atau bidan. Oleh karena itu, diperlukan Antenatal Care Analysis (ANC) untuk mengetahui apakah pola makan, pola asuh, dan sanitasi sudah terprogram dengan baik. Kerangka penelitian Antenatal Care (ANC) adalah model perbaikan metode. Model perbaikan metode terdiri dari indikator, metode yang diusulkan, tujuan, dan pengukuran. Indikatornya terdiri dari instrumen monitoring dan kunjungan kesehatan. Metode yang diusulkan menggunakan tahap pipeline agregasi. Data tersebut diolah dalam tahap pipeline aggregation. Data diperoleh dari dataset surveilan data time series. 
Tujuan penelitian adalah untuk menganalisis hasil penelitian secara akurat sesuai dengan metode yang diusulkan. Pengukuran analisis indikator dengan penerapan dashboard sebagai indikator kinerja pada hasil penelitian. Secara praktis, hasil penelitian ini diharapkan dapat menjadi pertimbangan Dinas Kesehatan dan instansi terkait dalam mengurangi atau bahkan mengangkat Desa Argodadi Sedayu di Yogyakarta sebagai non lokus stunting melalui monitoring pola makan, pola asuh, dan sanitasi yang terprogram dengan baik.

\section{Pendahuluan}

Kasus kematian ibu di Bantul tergolong tinggi. Kedaulatan masyarakat di media cetak pada 17 Juli 2019 diberitakan terdapat 7 kasus AKI (Angka Kematian Ibu) hingga pertengahan Juli 2019. Kepala Seksi Kemitraan Dinas Kesehatan Bantul, drg. Sapta Adisuka Mulyatno, Ph.D., menjelaskan angka AKI di Bantul 2018 mencapai 14 kasus. Prof. Dr. Hamam Hadi, MS, Sc.D Sp.GK menginformasikan bahwa 30,8 persen kasus stunting terdapat di Indonesia. Bantul merupakan sebuah kabupaten di Provinsi D.I. Yogyakarta, Indonesia, adalah tempat terjadinya stunting. Bantul ditemukan di 10 desa. Sepuluh desa tersebut antara lain Desa Patalan Jetis, Desa Canden Jetis, Desa Terong Dlingo, Desa Argodadi Sedayu, Desa Triharjo Pandak, Desa Triwidadi Pajangan, Desa Jatimulyo Dlingo, Desa Datangharjo Sewon, Desa Sendangsari Pajangan, dan Desa Trimulyo Jetis. Penelitian difokuskan di Desa Argodadi Sedayu. Antenatal Care (ANC) adalah pemeriksaan kehamilan oleh dokter atau bidan. Oleh karena itu, diperlukan Antenatal Care Analysis (ANC) untuk mengetahui apakah pola makan, pola asuh, dan sanitasi sudah terprogram dengan benar. Antenatal Care Analysis (ANC) menggunakan teknologi database NoSQL. Sistem database pengembangan NoSQL mendistribusikan database dalam skala besar [1]. Teknologi ini dapat membuat dan memungkinkannya diterapkan dalam studi kasus Antenatal Care (ANC). Database NoSQL sebagai penyedia beberapa properti yang tidak tersedia dalam database relasional seperti desain tanpa skema, skala horizontal, dan konsistensi [2]. NoSQL memiliki keunggulan seperti biaya operasional yang rendah, keandalan, portabilitas, dan ketersediaan [3].
Database NoSQL digunakan sebagai pengolahan untuk menyelesaikan masalah transaksional dan struktural [4]. NoSQL memiliki konsep evolusi perangkat lunak dan beberapa pendekatan untuk mendeteksi dan menganalisis evolusi skema database untuk berbagai jenis database [5]. Beberapa studi dengan penyimpanan data NoSQL telah dilakukan [6] [7] [8] [9] [10]. Peneliti mengusulkan analisis Antenatal Care (ANC) di Desa Argodadi Sedayu Yogyakarta. Peneliti mengajukan konsep NoSQL pada metode Aggregation Pipeline Stages. Peneliti berharap dengan adanya penelitian ini dapat menjadi pertimbangan Dinas Kesehatan dan instansi terkait dalam mengurangi atau bahkan mengangkat Desa Argodadi Sedayu Yogyakarta sebagai daerah non lokus stunting dengan hasil analisis dalam penelitian tersebut.

\section{Landasan Teori}

Tingkat kepuasan perawatan antenatal (ANC) dengan perawatan, tingkat kehadiran, hasil ibu dan bayi dimediasi dengan memberdayakan peningkatan kesehatan harapan hidup [11]. Desa Argodadi Sedayu, Yogyakarta, membutuhkan tindakan khususnya Antenatal Care (ANC), sebagai lokus stunting. Tindakan ini termasuk memberikan pola makan, pengasuhan anak, dan sanitasi untuk kegiatan pengawasan. Surveilans diartikan sebagai pengamatan terus menerus terhadap kondisi dan masalah kesehatan yang mempengaruhi risiko penyakit melalui proses pengumpulan data yang sistematis, mengolah, menganalisis, menginterpretasikan data menjadi informasi, dan menyebarluaskan informasi kepada penyelenggara program kesehatan dan pembuat kebijakan lainnya [12]. Konsep 
penelitian Antenatal Care (ANC) yang diusulkan dalam kegiatan surveilans menggunakan Aggregation Pipeline Stages Model. Model Aggregation Pipeline Stages digunakan untuk menggabungkan banyak informasi dengan tujuan membuat keputusan akhir tentang redundansi [13]. Adanya model Aggregation Pipeline Stages dapat mengurangi redudansi data sehingga model tersebut diharapkan dapat menghasilkan analisis yang akurat dengan pertimbangan dinas kesehatan dan instansi terkait. Pertimbangan dalam mengurangi atau bahkan membesarkan Desa Argodadi Sedayu di Yogyakarta sebagai daerah non lokus stunting dengan hasil studi tersebut.

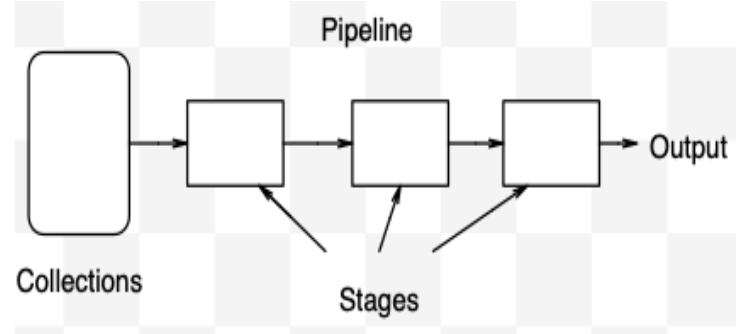

Gambar 1. Aggregation Pipeline Stages Design

Gambar 1 adalah desain database NoSQL yang akan digunakan dalam analisis Antenatal Care (ANC). Desain database relasional tidak mengakomodasi penyimpanan data tanpa desain hubungan dan batasan dalam integrasi skala ke beberapa server. Desain database NoSQL menyimpan dan memproses data dalam jumlah besar tanpa skema dengan cepat tanpa menggunakan model relasional. Kemampuan ini memberikan keuntungan dari dukungan arsitektur data skala besar yang lebih baik. Model tersebut mencakup nilai kunci, dokumen, kelompok kolom, dan bagan. NoSQL dengan model nilai kunci dan model grafik [14]. Model penelitian yang diusulkan dengan NoSQL ditemukan pada tahap awal bagian penting dari roadmap. Penelitian ini merupakan bagian dari roadmap penelitian. Penelitian ini terletak pada posisi / model utama. Gambar 2 menunjukkan roadmap penelitian. Arahan penelitian menuju Bigdata. Ruang penyimpanan data telah dikembangkan dengan perkembangan data. Ruang penyimpanan Relational Database Management System (SQL) akan menjadi database nonrelasional (NoSQL). Adanya teknologi NoSQL dapat membantu pengelolaan database. Database NoSQL digunakan sebagai pengolahan untuk menyelesaikan masalah transaksional dan struktural [15].

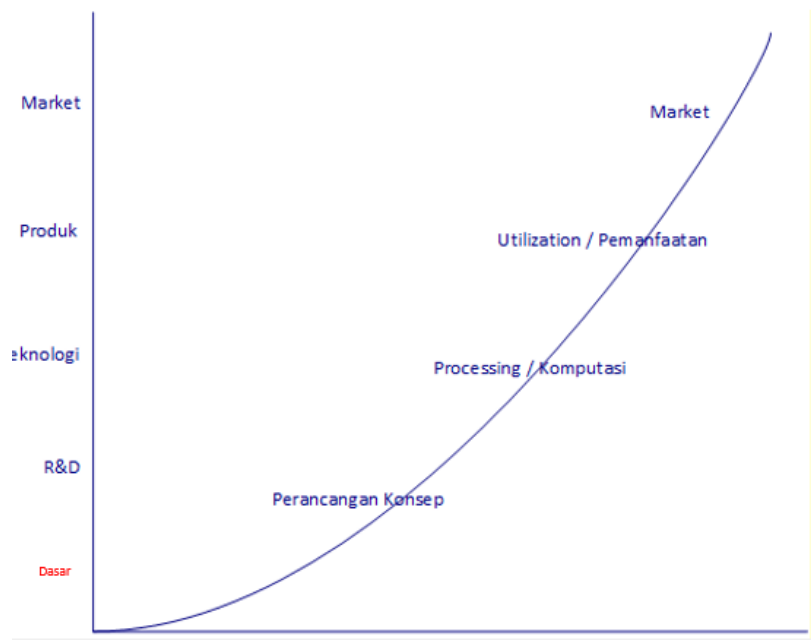

Gambar 2. Research Roadmap

Penelitian terkait terkait kesehatan ibu dan anak (KIA) tentang teknologi ditunjukkan pada tabel 1. Penelitian terkait teknologi penyimpanan data menggunakan konsep Relational Database Management System (SQL). Penerapan pengembangan database non relasional Sebuah teknologi penyimpanan data (NoSQL) ke Antenatal Care (ANC) dalam Pengawasan Kesehatan Ibu dan Anak mencakup pembaruan teknologi dalam penelitian penyimpanan data di bidang kesehatan.

Tabel 1. Penelitian Relevan

\begin{tabular}{|c|c|c|c|}
\hline No & Peneliti & Objek & Hasil \\
\hline 1 & $\begin{array}{l}\text { Andini } \\
\text { Aridewi, e } \\
\text { t al (2013) }\end{array}$ & $\begin{array}{l}\text { Analisis } \\
\text { Pemanfaatan } \\
\text { Bantuan } \\
\text { Operasional } \\
\text { Kesehatan } \\
\text { dalam Upaya } \\
\text { Peningkatan } \\
\text { Kesehatan Ibu } \\
\text { dan Anak di } \\
\text { Puskesmas } \\
\text { Wilayah Kerja } \\
\text { Dinas } \\
\text { Kesehatan } \\
\text { Kabupaten } \\
\text { Kudus }\end{array}$ & $\begin{array}{l}\text { Puskesmas yang } \\
\text { memanfaatkan } \\
\text { bantuan kesehatan } \\
\text { operasional secara } \\
\text { optimal untuk } \\
\text { segala upaya } \\
\text { peningkatan KIA } \\
\text { yang dilaksanakan } \\
\text { sesuai juknis telah } \\
\text { berhasil } \\
\text { menurunkan } \\
\text { angka kematian } \\
\text { ibu dan bayi serta } \\
\text { dapat meningkatkan } \\
\text { upaya KIA di } \\
\text { wilayahnya. }\end{array}$ \\
\hline 2 & $\begin{array}{l}\text { Munawar } \\
\text { oh (2014) }\end{array}$ & $\begin{array}{l}\text { Model } \\
\text { Informasi } \\
\text { Pemantauan } \\
\text { Kesehatan Ibu }\end{array}$ & $\begin{array}{l}\text { Pembentukan } \\
\text { program komputer } \\
\text { sstem informasi } \\
\text { manajemen }\end{array}$ \\
\hline
\end{tabular}




\begin{tabular}{|c|c|c|c|}
\hline & & $\begin{array}{l}\text { dan Bayi di } \\
\text { Posyandu } \\
\text { dalam Rangka } \\
\text { Upaya } \\
\text { Peningkatan } \\
\text { Kesehatan } \\
\text { Keluarga }\end{array}$ & posyandu \\
\hline 3 & $\begin{array}{l}\text { Armaya, } \\
\text { Sriatmi, } \\
\text { Arso, } \\
\text { Masyaraka } \\
\text { t, \& } \\
\text { Diponegor } \\
\text { o (2016) }\end{array}$ & $\begin{array}{l}\text { Analisis } \\
\text { Kinerja } \\
\text { Surveilans } \\
\text { Kesehatan } \\
\text { Program } \\
\text { Kesehatan Ibu } \\
\text { dan Anak di } \\
\text { Semarang }\end{array}$ & $\begin{array}{l}\text { Program belum } \\
\text { melaksanakan } \\
\text { pendampingan } \\
\text { ibu hamil dan } \\
\text { pendampingan } \\
\text { ibu nifas sesuai } \\
\text { ketentuan. Tidak } \\
\text { ada sistem } \\
\text { penilaian kerja } \\
\text { yang memiliki } \\
\text { indikator pasti. }\end{array}$ \\
\hline 4 & $\begin{array}{l}\text { Yanti, } \\
\text { Anwar, \& } \\
\text { Irvan } \\
(2016)\end{array}$ & $\begin{array}{l}\text { Hubungan } \\
\text { Implementasi } \\
\text { Sistem } \\
\text { Informasi } \\
\text { Berbasis } \\
\text { Website } \\
\text { dengan } \\
\text { Keakuratan } \\
\text { Data Anemia } \\
\text { pada } \\
\text { Kehamilan }\end{array}$ & $\begin{array}{l}\text { Pengembangan } \\
\text { aplikasi } \\
\text { monitoring anemia } \\
\text { pada kehamilan } \\
\text { berbasis website } \\
\text { merupakan upaya } \\
\text { efektif untuk } \\
\text { meningkatkan } \\
\text { akurasi pelaporan } \\
\text { anemia. }\end{array}$ \\
\hline 5 & $\begin{array}{l}\text { Sari \& } \\
\text { Nugraha } \\
(2016)\end{array}$ & \begin{tabular}{l} 
Sistem \\
Informasi \\
Pencatatan \\
dan Pelaporan \\
\multicolumn{1}{c}{ di } \\
Dinas \\
Kesehatan \\
Kabupaten \\
Kudus
\end{tabular} & $\begin{array}{l}\text { Sistem ini dapat } \\
\text { digunakan untuk } \\
\text { pengelolaan data } \\
\text { puskesmas, } \\
\text { pengelolaan data } \\
\text { pengguna } \\
\qquad \text { (user } \\
\text { ), pengelolaan } \\
\text { kategori cek, } \\
\text { pengelolaan data } \\
\text { SP3 KIA, } \\
\text { pengelolaan data } \\
\text { jumlah } \\
\text { permintaan } \\
\text { pemeriksaan. }\end{array}$ \\
\hline 6 & $\begin{array}{l}\text { Mengkasri } \\
\text { nal, } \\
\text { Maiyana, } \\
\& \quad \text { Silvia } \\
(2018)\end{array}$ & $\begin{array}{l}\text { Perancangan } \\
\text { Sistem } \\
\text { Informasi } \\
\text { Posyandu Lasi } \\
\text { Kecamatan } \\
\text { Canduang } \\
\text { Kabupaten } \\
\text { Agam } \\
\text { Sumatera } \\
\text { Barat Berbasis } \\
\text { Web Android }\end{array}$ & $\begin{array}{l}\text { Adanya fasilitas } \\
\text { forum dan chat } \\
\text { room dapat } \\
\text { memfasilitasi } \\
\text { komunikasi dan } \\
\text { memudahkan } \\
\text { dalam } \\
\text { memberikan } \\
\text { jawaban atas } \\
\text { keraguan dalam } \\
\text { Hubungan }\end{array}$ \\
\hline
\end{tabular}

\begin{tabular}{|c|c|c|c|}
\hline & & & $\begin{array}{l}\text { kesehatan ibu dan } \\
\text { anak untuk } \\
\text { meningkatkan } \\
\text { pemahaman } \\
\text { masyarakat } \\
\text { tentang kesehatan } \\
\text { ibu dan anak }\end{array}$ \\
\hline 7 & $\begin{array}{l}\text { Ida } \\
\text { Sugiarti, } \\
\text { Arief } \\
\text { Tarmansya } \\
\text { h (2018) }\end{array}$ & $\begin{array}{l}\text { Pengembang } \\
\text { an Sistem } \\
\text { Informasi } \\
\text { Posyandu } \\
\text { Terpadu } \\
\text { (SIPTER) di } \\
\text { Puskesmas } \\
\text { Tawang } \\
\text { Kecamatan } \\
\text { Tawang Kota } \\
\text { Tasikmalaya }\end{array}$ & $\begin{array}{l}\text { SIPTER di } \\
\text { Posyandu dengan } \\
\text { segala } \\
\text { keterbatasannya, } \\
\text { pengolahan data } \\
\text { dari pelayanan } \\
\text { posyandu menjadi } \\
\text { lebih cepat, akurat } \\
\text { dan prosesnya } \\
\text { semakin } \\
\text { memudahkan serta } \\
\text { membantu kader } \\
\text { posyandu dalam } \\
\text { menjalankan } \\
\text { tugasnya. }\end{array}$ \\
\hline 8 & $\begin{array}{l}\text { Chusyairi, } \\
\text { Kurnia } \\
\text { Hadi } \\
\text { Muktining } \\
\text { Nur, \& } \\
\text { Haryanto } \\
(2018)\end{array}$ & $\begin{array}{l}\text { Sistem Jadwal } \\
\text { Imunisasi } \\
\text { Kesehatan } \\
\text { Bayi dan Balita } \\
\text { Berbasis Sms } \\
\text { Gateway }\end{array}$ & $\begin{array}{l}\text { Pelayanan pada } \\
\text { sisteM informasi } \\
\text { kesehatan bayi } \\
\text { dan balita dapat } \\
\text { menampilkan } \\
\text { hasil sesuai } \\
\text { dengan } \\
\text { kebutuhan } \\
\text { Posyandu dalam } \\
\text { menginformasika } \\
\mathrm{n} \text { jadwal } \\
\text { imunisasi. }\end{array}$ \\
\hline 9 & $\begin{array}{l}\text { Rusdiana } \\
\& \\
\text { Setiawan } \\
(2018)\end{array}$ & $\begin{array}{l}\text { Aplikasi } \\
\text { riwayat } \\
\text { konseling } \\
\text { kehamilan } \\
\text { untuk ibu } \\
\text { hamil berbasis } \\
\text { mobile android }\end{array}$ & $\begin{array}{l}\text { Aplikasi dapat } \\
\text { membantu ibu } \\
\text { hamil sebagai } \\
\text { pengguna aplikasi } \\
\text { dalam melakukan } \\
\text { penyuluhan } \\
\text { kesehatan } \\
\text { kehamilan, } \\
\text { sehingga tidak } \\
\text { perlu membawa } \\
\text { buku KIA setiap } \\
\text { akan melakukan } \\
\text { penyuluhan. }\end{array}$ \\
\hline 10 & $\begin{array}{l}\text { Ode, } \\
\text { Rahman, } \\
\text { Handiyani, } \\
\text { \& Chandra } \\
\text { (2019) }\end{array}$ & $\begin{array}{l}\text { Pendampinga } \\
\mathrm{n} \quad \text { Sistem } \\
\text { Informasi } \\
\text { Posyandu } \\
\text { Terintegrasi } \\
\text { untuk } \\
\text { Meningkatkan } \\
\text { Efikasi Diri }\end{array}$ & $\begin{array}{l}\text { Sistem informasi } \\
\text { posyandu ini } \\
\text { terus } \\
\text { dikembangkan } \\
\text { agar sesuai } \\
\text { dengan informasi } \\
\text { yang dibutuhkan } \\
\text { oleh pemegang } \\
\text { kebijakan. } \\
\text { Informasi } \\
\text { tambahan dapat } \\
\text { dilakukan } \\
\text { melalui admin } \\
\text { sistem. }\end{array}$ \\
\hline 11 & Muslamet, & Implementa & $\begin{array}{lll}\text { SIM } & \text { KIA yang }\end{array}$ \\
\hline
\end{tabular}

IJUBI - VOL. 4 No. 1 (2021): 16 - 24 


\begin{tabular}{|c|c|c|c|}
\hline & $\begin{array}{l}\text { Suryoputr } \\
\text { o, \& } \\
\text { Mawarni } \\
(2019)\end{array}$ & $\begin{array}{l}\text { si Sistem } \\
\text { Informasi } \\
\text { Manajemen } \\
\text { Kesehatan } \\
\text { Ibu dan } \\
\text { Anak (SIM } \\
\text { KIA) } \\
\text { dengan } \\
\text { Pendekatan } \\
\text { Kesesuaian } \\
\text { Teknologi } \\
\text { Tugas di } \\
\text { Puskesmas } \\
\text { Rowosari } \\
\text { Kota } \\
\text { Semarang }\end{array}$ & $\begin{array}{l}\text { sekarang berjalan } \\
\text { bukan } \\
\text { merupakan tugas } \\
\text { bidan dalam } \\
\text { mengumpulkan, } \\
\text { mencatat, } \\
\text { mengelola, dan } \\
\text { melaporkan data } \\
\text { PWS KIA }\end{array}$ \\
\hline 12 & $\begin{array}{l}\text { Wicahyon } \\
\text { o, } \\
\text { Setyanto, } \\
\text { \& Raharjo } \\
(2019)\end{array}$ & $\begin{array}{l}\text { Aplikasi } \\
\text { Ponsel } \\
\text { Kelahiran } \\
\text { Cerdas untuk } \\
\text { Memantau } \\
\text { Wanita Hamil }\end{array}$ & $\begin{array}{l}\text { Pengujian } \\
\text { perkiraan jarak } \\
\text { asli dengan } \\
\text { perkiraan jarak } \\
\text { yang tercatat } \\
\text { dalam aplikasi } \\
\text { menunjukkan } \\
\text { jarak yang hampir } \\
\text { identik. }\end{array}$ \\
\hline 13 & $\begin{array}{l}\text { Julizal, } \\
\text { Lukman, \& } \\
\text { Sunoto } \\
(2019)\end{array}$ & $\begin{array}{l}\text { Perancangan } \\
\text { Aplikasi } \\
\text { Sistem } \\
\text { Pemantauan } \\
\text { Tumbuh } \\
\text { Kembang } \\
\text { Anak Sebagai } \\
\text { Alat Deteksi } \\
\text { Tumbuh } \\
\text { Kembang }\end{array}$ & $\begin{array}{l}\text { Sistem Aplikasi } \\
\text { Pengolahan Data } \\
\text { Balita di } \\
\text { Posyandu } \\
\text { Bougenvile untuk } \\
\text { warga Depok } \\
\text { berbasis Jawa } \\
\text { dapat membantu } \\
\text { dan } \\
\text { mempermudah } \\
\text { dalam } \\
\text { pengolahan data } \\
\text { laporan kegiatan } \\
\text { di Posyandu } \\
\text { Bougenvile }\end{array}$ \\
\hline 14 & $\begin{array}{l}\text { Wylie et } \\
\text { al. (2012) }\end{array}$ & $\begin{array}{l}\text { Penggunaan } \\
\text { NoSQL untuk } \\
\text { analisis } \\
\text { jaringan } \\
\text { streaming }\end{array}$ & $\begin{array}{l}\text { Penggunaan } \\
\text { pendekatan } \\
\text { agregasi pipeline } \\
\text { NoSQL untuk } \\
\text { analisis data real- } \\
\text { time pada aliran } \\
\text { data jaringan. } \\
\text { Peneliti } \\
\text { menemukan } \\
\text { bahwa } \\
\text { pendekatan yang } \\
\text { menggunakan } \\
\text { database NoSQL } \\
\text { memungkinkan } \\
\text { untuk analisis } \\
\text { data jaringan }\end{array}$ \\
\hline
\end{tabular}

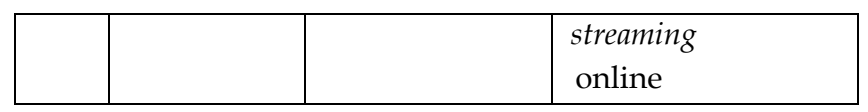

\section{Metode}

Kerangka penelitian adalah model perbaikan metode. Model perbaikan metode terdiri dari indikator, metode yang diusulkan, tujuan, dan pengukuran. Indikatornya terdiri dari instrumen monitoring dan kunjungan kesehatan. Metode yang diusulkan menggunakan tahap pipeline agregasi. Data tersebut diolah dalam tahap pipeline aggregation. Data diperoleh dari dataset surveilans data time series di Sedayu Yogyakarta. Tujuan penelitian adalah menganalisis hasil penelitian secara akurat sesuai dengan metode yang diusulkan yaitu pengukuran analisis indikator dengan menggunakan dashboard sebagai indikator kinerja hasil penelitian. Gambar 3 menunjukkan kerangka penelitian.

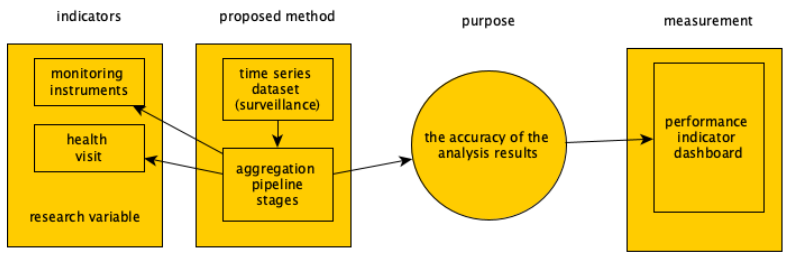

Gambar 3. Desain Kerangka Penelitian

Model pengembangan analisis mengadopsi pendekatan model pengembangan sistem scrum tangkas. Diagram alir pendekatan analisis penelitian ditunjukkan pada Gambar 4 .

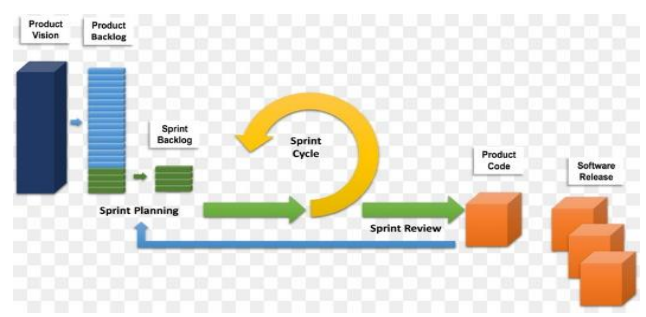
Gambar 4. Diagram Alir Pendekatan Analisis
Penelitian

Product Vision merupakan tahap perencanaan ke arah pengembangan dalam penelitian. Product vision merupakan rumusan masalah yang meliputi bagaimana memanfaatkan hasil analisis penelitian dengan mempertimbangkan Dinas Kesehatan dan instansi terkait dalam penanggulangan Desa Argodadi Sedayu Yogyakarta sebagai daerah non lokus stunting. 
Product Backlog ditetapkan sebagai tujuan penelitian yaitu Analisis Antenatal Care (ANC) surveilans kesehatan ibu dan anak di Sedayu Yogyakarta dengan Tahapan NoSQL Aggregation Pipeline. Sprint Backlog adalah tahap implementasi model yang dirancang. Sprint Cycle dan Sprint Review mengevaluasi tahapan desain model kasus Antenatal Care (ANC) pada surveilans kesehatan ibu dan anak di Sedayu Yogyakarta. Kode Produk menerapkan model Aggregation Pipeline Stages NoSQL untuk kasus Antenatal Care (ANC) dalam surveilans kesehatan ibu dan anak di Sedayu Yogyakarta. Software Release merupakan tahap pengujian model. Sprint Planning, tahapan perancangan dan perbaikan sistem sesuai evaluasi uji coba model. Teknik pengumpulan data yaitu: data hasil analisis surveilans Antenatal Care (ANC) bidang kesehatan ibu dan anak di Sedayu Yogyakarta. Data berupa Antenatal Care (ANC) trimester I. Secara umum, metode penelitian mengikuti aturan standar. Mulai dari studi pustaka, analisis kebutuhan pengumpulan data dan informasi, evaluasi, dan representasi hasil. Gambar 5 menunjukkan diagram alir penelitian. Studi literatur penelitian Antenatal Care Analysis (ANC) tentang kesehatan ibu dan anak di Sedayu Yogyakarta meliputi pencarian sumber informasi melalui arsip, buku, jurnal, makalah, dan laporan penelitian. Pengumpulan data dan penelitian pengumpulan informasi Antenatal Care Analysis (ANC) tentang kesehatan ibu dan anak di Sedayu Yogyakarta meliputi wawancara, dokumentasi, dan observasi. Analisis masalah penelitian Antenatal Care Analysis (ANC) pada kesehatan ibu dan anak di Sedayu Yogyakarta meliputi identifikasi hasil analisis, analisis sistem yang ada, dan analisis kelemahan. Evaluasi penelitian Antenatal Care Analysis (ANC) tentang kesehatan ibu dan anak di Sedayu Yogyakarta meliputi pengujian sensitivitas dan akurasi.

\section{Hasil dan Pembahasan}

Hasil implementasi ditunjukkan pada Gambar 5 sampai dengan Gambar 9. Gambar 5 menunjukkan pengenalan halaman awal. Implementasi sistem menggunakan express framework dengan database NoSQL (MongoDB).

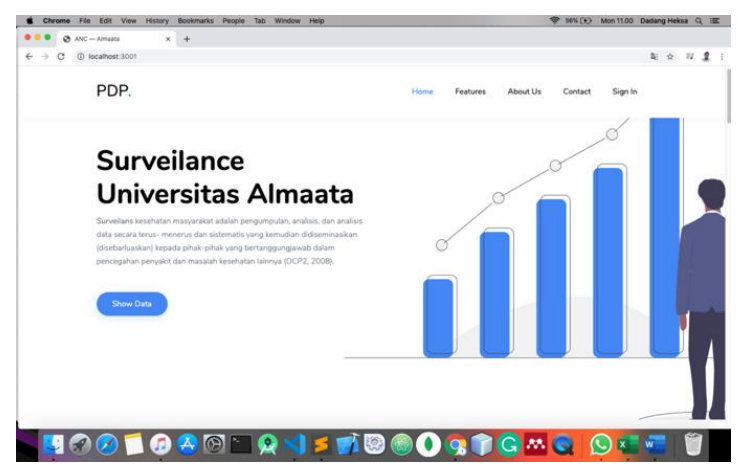

Gambar 5. pengantar tampilan frontend

Gambar 6 menunjukkan halaman login. Halaman login berisi nama pengguna dan kata sandi. Di halaman login, kami memeriksa algoritme enkripsi HMAC menggunakan HMAC 256.

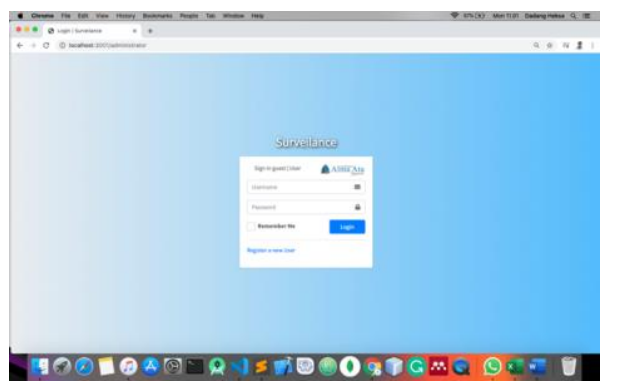

Gambar 6. tampilan halaman login

Gambar 7 menunjukkan tampilan infografis pendidikan terkini - berbagai jenjang pendidikan di masyarakat Sedayu, Bantul, D.I. Yogyakarta meliputi pendidikan dasar, sekolah menengah, hingga pendidikan tinggi dengan lulusan S3.

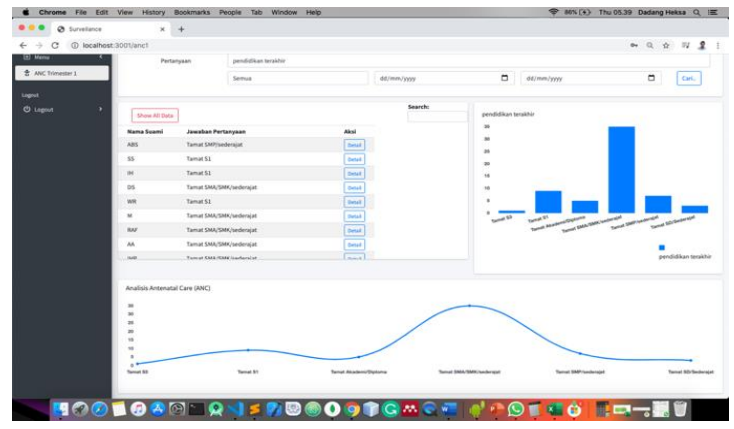

Gambar 7. Tampilan dasbor indicator kinerja infografis Pendidikan terbaru

Gambar 8 menunjukkan tampilan dasbor dari statistik pekerjaan saat ini. Pekerjaan masyarakat Sedayu bermacam-macam, antara lain PNS / TNI / POLRI, pengusaha, petani / peternak / nelayan, buruh / buruh tani, ibu rumah tangga / tidak bekerja, hingga pekerja lepas. 


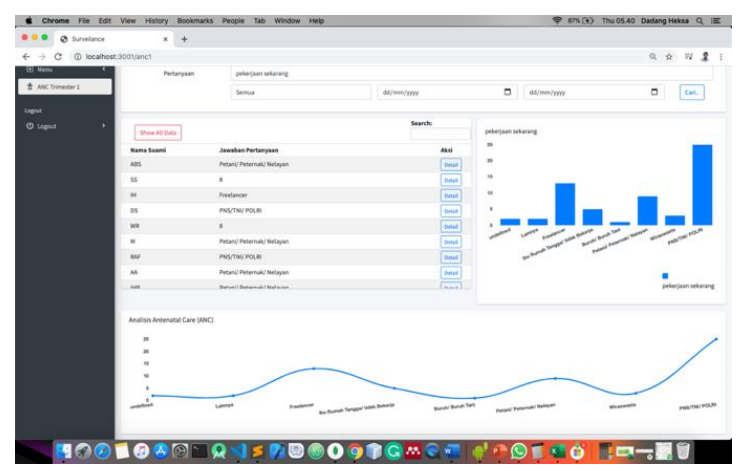

Gambar 8. Tampilan dasbor indikator kinerja statistik pekerjaan saat ini

Gambar 9 menunjukkan tampilan dashboard alasan memilih tempat $\mathrm{k} 1$. Alasan memilih tempat $\mathrm{k} 1$ adalah pelayanan yang baik.

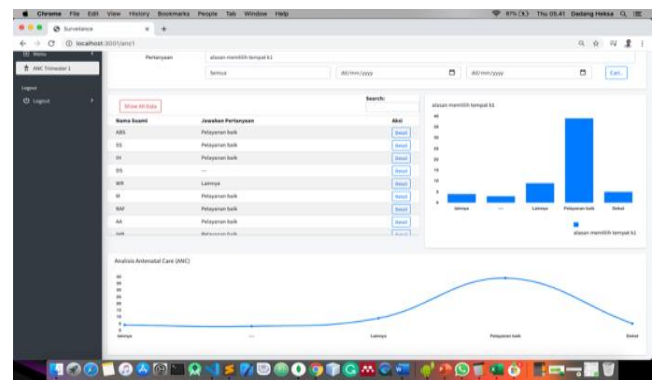

Gambar 9. Dasbor indikator kinerja menampilkan alasan memilih tempat $\mathrm{k} 1$

Pengujian evaluasi sistem menggunakan uji sensitivitas dan spesifisitas. Uji sensitivitas dan spesifisitas dashboard analisis asuhan antenatal didapatkan model sesuai tabel 2 .

Tabel 2. Rumus perhitungan sensitivitas dan akurasi

\begin{tabular}{|c|c|c|c|c|}
\hline & & \multicolumn{3}{|c|}{$\begin{array}{c}\text { aggregation pipeline } \\
\text { (ANC data) }\end{array}$} \\
\hline & $\begin{array}{c}\text { Test } \\
\text { results } \\
\text { (Responde } \\
\text { nt Data) }\end{array}$ & $\begin{array}{c}\text { appropria } \\
\text { te }\end{array}$ & $\begin{array}{c}\text { It is not } \\
\text { in } \\
\text { accordan } \\
\text { ce with }\end{array}$ & total \\
\hline $\begin{array}{c}\text { aggregati } \\
\text { on } \\
\text { pipeline } \\
\text { (ANC } \\
\text { inquiries } \\
\text { Appropria } \\
\text { te }\end{array}$ & $\begin{array}{c}\text { It } \text { is not in } \\
\text { accordanc } \\
\text { e with }\end{array}$ & $c$ & $b$ & $a+b$ \\
\cline { 2 - 5 } & Total & $a+c$ & $b+d$ & $\begin{array}{c}a+b+c \\
+d\end{array}$ \\
\hline
\end{tabular}

"A" adalah subjek yang diprediksi oleh pertanyaan ANC dan data ANC benar (positif benar); "B" adalah subjek yang diprediksi oleh pertanyaan ANC sesuai oleh prediktor dan data ANC tidak sesuai (positif palsu); "C" adalah subjek yang diprediksi oleh pertanyaan ANC tidak sesuai oleh prediktor dan data ANC sesuai dengan (negatif palsu); "D" adalah subjek yang diprediksi oleh pertanyaan ANC tidak sesuai dengan prediktor dan data anc (negatif nyata). Data Anc terdiri dari 60 responden, dan pertanyaan anc terdiri dari 164 item. Gambar 7, Gambar 8. Tampilan dasbor indikator kinerja statistik pekerjaan saat ini, dan Gambar 9. Dasbor indikator kinerja menampilkan alasan memilih tempat $\mathrm{k} 1$ adalah contoh item pertanyaan yang menggunakan pipeline agregasi dengan data responden. Pengujian sensitivitas dengan rumus persamaan (2). Uji akurasi dihitung dengan persamaan (1).

accuracy $=\frac{(a+d)}{(a+b+c+d)}$

sensitivity $=\frac{(a)}{(a+c)}$

Tabel 3. Hasil perhitungan sensitivitas dan akurasi

\begin{tabular}{|c|c|c|c|c|}
\hline & & \multicolumn{3}{|c|}{$\begin{array}{l}\text { aggregation pipeline } \\
\text { (ANC data) }\end{array}$} \\
\hline & $\begin{array}{c}\text { Test } \\
\text { results } \\
\text { (Responde } \\
\text { nt Data) }\end{array}$ & $\begin{array}{c}\text { appropria } \\
\text { te }\end{array}$ & $\begin{array}{c}\text { It is not } \\
\text { in } \\
\text { accordanc } \\
\text { e with }\end{array}$ & $\begin{array}{c}\text { tota } \\
l\end{array}$ \\
\hline \multirow{3}{*}{$\begin{array}{c}\text { aggregatio } \\
\text { n pipeline } \\
\text { (ANC } \\
\text { inquiries) }\end{array}$} & $\begin{array}{c}\text { appropriat } \\
e\end{array}$ & 60 & 0 & 60 \\
\hline & $\begin{array}{c}\text { It is not in } \\
\text { accordance } \\
\text { with }\end{array}$ & 0 & 0 & 0 \\
\hline & Total & 60 & 0 & 60 \\
\hline
\end{tabular}

Tabel 3 menunjukkan bahwa sensitivitas dan akurasi model yang dibangun dengan sistem analisis pipeline aggregation menunjukkan hasil $100 \%$.

\section{Kesimpulan dan Saran}

Hasil analisis perawatan antenatal dengan agregasi pipeline dapat dilakukan dan diuji kepekaan dan akurasinya. Agregasi pipeline dibentuk dari pertanyaan perawatan antenatal dan data perawatan antenatal. Pembentukan dasbor indikator kinerja dapat dilakukan dengan agregasi pipeline.

\section{Ucapan Terimakasih}

Penulis mengucapkan terima kasih kepada Kementerian Pendidikan dan Kebudayaan yang telah memberikan dukungan berupa hibah penelitian sehingga terlaksana dengan baik dan diperoleh hasil penelitian. 


\section{Referensi}

[1] M. Banane, A. Belangour, and E. H. Labriji, "RDF Data Management Systems Based on NoSQL Databases: A Comparative Study," Int. J. Comput. Trends Technol., vol. 58, no. 2, pp. 98-102, 2018, doi: 10.14445/22312803/ijcttv58p117.

[2] M. Diogo, B. Cabral, and J. Bernardino, "Consistency models of NoSQL databases," Futur. Internet, vol. 11, no. 2, pp. 1-19, 2019, doi: 10.3390/fi11020043.

[3] S. Ramzan, I. S. Bajwa, R. Kazmi, and Amna, "Challenges in NoSQL-based distributed data storage: A systematic literature review," Electron., vol. 8, no. 5, 2019, doi: 10.3390/electronics8050488.

[4] M. R. Ahmed, M. A. Khatun, M. A. Ali, and K. Sundaraj, "A literature review on NoSQL database for big data processing," Int. J. Eng. Technol., vol. 7, no. 2, pp. 902-906, 2018, doi: 10.14419/ijet.v7i2.12113.

[5] L. Fung Ji, N. Firdaus Mohd Azmi, S. Sophiayati Yuhaniz, T. Malaysia, J. Sultan Yahya Petra, and K. Lumpur, "Software Evolution: A Review on Approaches in Handling Database Schema," Open Int. J. Informatics, vol. 6, no. 3, pp. 11-20, 2018.

[6] F. I. Sanjaya and D. Heksaputra, "Prediksi Rerata Harga Beras Tingkat Grosir Indonesia dengan Long Short Term Memory," JATISI (Jurnal Tek. Inform. dan Sist. Informasi), vol. 7, no. 2, pp. 163-174, 2020, doi: 10.35957/jatisi.v7i2.388.

[7] D. Heksaputra, "FUZZY INTELLIGENCE SYSTEM FOR EMPLOYEE ASSESSMENT: A CASE STUDI OF XYZ UNIVERSITY IN YOGYAKARTA," Indones. J. Bus. Intell., vol. 1, no. 1, pp. 39-44, 2018.

[8] I. Muhimmah, D. Heksaputra, and Indrayanti, "Color feature extraction of HER2 Score 2+ overexpression on breast cancer using Image Processing," MATEC Web Conf., vol. 154, pp. 2-6, 2018, doi: 10.1051/matecconf/201815403016.
[9] D. Puspasari, D. Heksaputra, and M. Irfanudin, "Sistem Penilaian Manajemen Stres dengan Variabel Fuzzy pada Pasien Rumah Sakit," vol. 6, no. 1, pp. 1-9, 2020.

[10] F. Indra Sanjaya and D. Heksaputra, "Sistem Pendukung Keputusan Pemilihan Tenaga Kontrak Melalui Pendekatan Fuzzy Inference System dengan Metode Tsukamoto (Studi Kasus PT. Solo Murni)," Semin. Nas. Apl. Teknol. Inf., pp. 1907-5022, 2016.

[11] L. J. Hunter et al., "Better together: A qualitative exploration of women's perceptions and experiences of group antenatal care," Women and Birth, vol. 32, no. 4, pp. 336-345, 2019, doi: 10.1016/j.wombi.2018.09.001.

[12] K. K. RI, Surveilans Kesehatan Anak. Kementerian Kesehatan RI 2014, 2014.

[13] P. P. R. Arif Ahmed, Debi Prosad Dogra, Samarjit Kar, "Surveillance Scene Representation and Trajectory Abnormality Detection Using Aggregation of Multiple Concepts." Expert Systems With Applications Received, pp. 1-38, 2018.

[14] D. Mahajan, C. Blakeney, and Z. Zong, "Improving the energy efficiency of relational and NoSQL databases via query optimizations," Sustain. Comput. Informatics Syst., vol. 22, pp. 120-133, 2019, doi: 10.1016/j.suscom.2019.01.017.

[15] A. Ahmed, D. . Dogra, S. Kar, and P. . Roy, "Surveillance Scene Representation and Trajectory Abnormality Detection Using Aggregation of Multiple Concepts," Expert Syst. Appl., vol. 101, pp. 43-55, 2018, doi: https://doi.org/10.1016/j.eswa.2018.02. 013.

[16] A. Aridewi, M. I. Kartasurya, and A. Sriatmi, "Analisis Pemanfaatan Bantuan Operasional Kesehatan dalam Upaya Peningkatan Kesehatan Ibu dan Anak di Puskesmas Wilayah Kerja Dinas Kesehatan Kabupaten Kudus," J. Manaj. Kesehat. Indones., vol. 01, no. 01, pp. 3240, 2013.

[17] Siti Munawaroh, "Model Informasi 
Monitoring Kesehatan Ibu dan Bayi pada

Posyandu dalam Rangka Upaya Peningkatan Kesehatan Keluarga," Din. J. Teknol. Inf., vol. 19, no. 1, pp. 76-85, 2014.

[18] P. Armaya, A. Sriatmi, S. P. Arso, F. K. Masyarakat, and U. Diponegoro, "Analisis Kinerja Tenaga Surveilans Kesehatan ( Gasurkes ) Program," J. Kesehat. Masy., vol. 4, pp. 112-121, 2016.

[19] Y. Yanti, A. D. Anwar, and A. Irvan, "Hubungan Penerapan Sistem Informasi Berbasis Website Terhadap Akurasi Data Anemia Dalam Kehamilan," J. Bimtas, vol. 3, no. 1, 2016.

[20] I. R. Sari and F. Nugraha, "SISTEM INFORMASI PENCATATAN DAN PELAPORAN PUSKESMAS PROGRAM KESEHATAN IBU DAN ANAK PADA DINAS KESEHATAN KABUPATEN KUDUS," J. SIMETRIS, vol. 7, no. 1, pp. 251-256, 2016.

[21] T. Mengkasrinal, E. Maiyana, and S. Silvia, "Perancangan Sistem Informasi Posyandu Lasi Kec Canduang Kab Agam Sumbar Berbasis Web Android," Pros. SISFOTEK, vol. 2, no. 1, pp. 146-153, 2017, [Online]. Available: http://seminar.iaii.or.id/index.php/SIS FOTEK/article/view/70.

[22] I. Sugiarti, A. Tarmansyah, and F. A. Junaedi, "Pengembangan Sistem Informasi Posyandu Terintegrasi (Sipter) Di Wilayah Puskesmas Tawang Kecamatan Tawang Kota Tasikmalaya," Semin. Nas. dan Disem. Has. Pengabdi. Kpd. Masy. Berbas. Ris. Politek. Kesehat. Kemenkes Tasikmalaya, no. April, pp. 118123, 2018.

[23] A. Chusyairi, T. K. H. M. Nur, and D. Haryanto, "Sistem Informasi Jadwal Imunisasi Kesehatan Bayi Dan Balita Berbasis SMS Gateway," J. Teknol. Inf., vol. 13, no. 1, pp. 38-43, 2018.

[24] L. Rusdiana and H. Setiawan, "Aplikasi riwayat konseling kehamilan untuk ibu hamil berbasis mobile android," Pros. SNRT (Seminar Nas. Ris. Ter., pp. 7-14, 2018.
[25] L. Ode, A. Rahman, H. Handiyani, and M. Chandra, "PENDAMPINGAN SISTEM INFORMASI POSYANDU TERINTEGRASI MENINGKATKAN EFIKASI DIRI," J. Publ. Kebidanan, vol. 10, no. 1, pp. 150-159, 2019.

[26] A. Muslamet, A. Suryoputro, and A. Mawarni, "PELAKSANAAN SISTEM INFORMASI MANAJEMEN KESEHATAN IBU DAN ANAK (SIM KIA) DENGAN PENDEKATAN TASK TECHNOLOGY FIT (TTF) DI PUSKESMAS ROWOSARI KOTA SEMARANG," J. Kesehat. Masy., vol. 7, no. 1, pp. 11-19, 2019.

[27] G. Wicahyono, A. Setyanto, and S. Raharjo, "Aplikasi Mobile Smart Birth Untuk Monitoring Ibu Hamil," J. IT CIDA, vol. 5, no. 1, pp. 53-60, 2019.

[28] Julizal, Lukman, and I. Sunoto, "RANCANG BANGUN APLIKASI SISTEM MONITORING PERTUMBUHAN ANAK SEBAGAI ALAT DETEKSI PERTUMBUHAN," STRING (Satuan Tulisan Ris. dan Inov. Teknol., vol. 5, no. 1, pp. 1-11, 2019.

[29] B. Wylie, D. Dunlavy, W. D. Iv, and J. Baumes, "Using No SQL Databases for Streaming Network Analysis," SAND2012, 2012. 